\title{
Ojo Kuwwi song As Communist Discourse Formation In the election of the President of the Republic of Indonesia in 2014
}

\author{
Arhamuddin Ali \\ Graduate School of Indonesia Institute of the Arts Yogyakarta \\ email: ali.arhamuddin@yahoo.com
}

\begin{abstract}
The aim of this research is to find answers to song Ojo Kuwi as media of the Republic of Indonesia's presidential election campaign of 2014. In addition, another purpose is to reveal the campaign messages that are communicated through this song's lyric. This case study focuses on the study of Ojo Kuwi song along with talk on the Internet news media. Data collected from Internet news, analysis of musical elements and lyrics Ojo Kuwi. As a result of research, discovered an attempt to revive the collective memory of Indonesian communism society. Furthermore, the messages are communicated in Ojo Kuwi lyrics urge people to choose presidential number 1 candidate by providing an explanation of the shortcomings of his opponent.
\end{abstract}

Keywords: music, politics, campaign, memory

\section{INTRODUCTION}

Initial idea of this article came from a political phenomenon in Indonesia. In 2014 is the culmination of a political battle that seat two pairs of presidential candidates to compete for the seat of President of the Republic of Indonesia. Both are Prahara (Prabowo-Hatta Rajasa) and Jokowi JK (Joko Widodo-Jusuf Kalla). Each pair of candidates is supported by two major political force in Indonesia, KMP (Koalisi Merah Putih) or the Coalition Red and White and KIH (Koalisi Indonesia Hebat) or the Coalition Indonesia Super. KMP that carries Prahara supported by several large parties include Gerindra (Gerakan Indonesia Merdeka) or Free Indonesia Movement Party, PPP (Partai Persatuan Pembangunan) or the United Development Party, Golkar (Gologan Karya) the Functional Group, PKS (Partai Keadilan Sejahtera) or the Prosperous Justice Party and PAN (Partai Amanat Nasional) or the National Mandate Party. While KIH carrying Jokowi-JK and supported by PDIP (Partai Demokrasi Indonesia Perjuangan) or the Indonesian Democratic Party of Struggle, PKB (Patai Kebangkitan Bangsa) or the National Awakening Party, Hanura (Hati Nurani Rakyat) or People's Conscience Party and the Nasdem (Nasional Demokrasi) or National Democratic Party.

It's unique in Indonesian political battle this time was the way the both winning team candidates attract public sympathy through the campaign. Like the previous 
presidential election, political campaigns synonymous with the use of media, both print and electronic media. But in the 2014 presidential election, there are new shades, namely the involvement of musicians and music as a campaign tool. Ahmad Dhani appoint as one of the members prahara campaign teams. Ahmad Dhani create a campaign song for Prahara. While Jokowi-JK designate a group Slank music as a member of the campaign team. They are popular with the title song “Hail Two Fingers” (Salam Dua Jari).

The use of music as a campaign tool does not end there. An article by Gunawan (Kompas, 24/6/2014) describes the involvement of musicians in the Indonesian presidential election in 2014. In his writings he explained the involvement of Jogja Hip Hop musicians Foundation is campaigning Marzuki Mohamad Jokowi-JK with the song "Bersatu Padu Coblos No. 2 ". In addition, the article shows the Prahara support group inspired from the song "Happy" singer's US Pharrel Williams.

From some of the examples above, there is one song that controversy in Indonesian society. Ojo Kuwi song, one piece of music composed by Ahmad Dhani which is used as a form of support to Prahara. The song which allegedly resembles Genjer-Genjer song became a major conversation internet media in Indonesia. Genjer-Genjer is one song that was banned in the new order as identified with the latent danger of communism at the time. However, in the 2014 presidential election campaign Indonesia discourse on track Genjer-Genjer back Ojo Kuwi discussed since the song circulating on Youtube.

Based on the above, I suspect memory politics practiced by Prahara camp. Thus, in this paper will describe the reality of the politics of memory as a campaign communication strategy.

From the above description, this study will answer two questions. Among others, as follows:

1. Why the song Ojo Kuwi mimic elements of music Genjer-Genjer songs?

2. How to form a political message communicated in song Ojo Kuwi?

\section{THEORETICAL BASIS}

Before the much discussed political issues of memory, we first discuss about the concept of collective memory. According to the Olick explanation (1999), the memory associated with past experience and embedded in the minds and did not realize the human form itself. To recall past experiences, the memory requires something as stimulus. One is the environment or public space.

The phenomenon of Indonesian presidential election campaign in 2014 has met the public spaces. There are two concepts of public space, namely physical and non-physical space. As according to Low and Smith (2006), the physical space include roads, parks, shopping centers. While the non-physical space, among others, the media and the Internet. In this paper, the concept used is the nonphysical space. Because, talks about the presidential campaign using songs Ojo 
Kuwi derived from Youtube and discussed in the media Internet.

Talks about the memory also discussed in the study of music. One model studies of memory in music is the study of Psychology of Music. Bob Sneyder (2001) divides the two forms of memory in the human body, namely the long-term memory (LTM) obtained from events not conscious or subconscious. While the second is a short-term memory (STM), this memory is obtained from new information. This new information is brought or revive human LTM (2001: 4-5). Associated with music, Sneyder explain elements of music like pitch and melodic intervals have the relationship with human expectations (2001: 135). In this regard, attention to aspects of Ojo Kuwi melody will become a major concern in this study as a stimulus that evokes the collective memory of the community. Apart from the explanation of the memory, this paper also uses the concept of a communications strategy in political campaigns. Burton and Shea (2010) explains that the media is one tool for communicating campaign messages. He introduced the concept of "message box" in the media strategy. There are four main points are communicated in this concept. First, What you say about you? Secondly, What they say about you? Third, What you say about them? Fourth, What they say about them? (2006: 160).

\section{RESEARCH METHODOLOGY}

This study used a qualitative methodology and the case study method. Both are used because based on the data that will be analyzed in the study. Some of the data collected manifold qualitative data sourced from the internet news related to political campaigns Indonesian presidential election of 2014, in particular that addresses the following issues Ojo Kuwi song along with a variety of dimensions. Additionally, in this study also analyzed the data recorded audio track Ojo Kuwi which is then compared with the song Genjer-Genjer. Aspects lyrics Ojo Kuwi also be one source of data.

\section{RESEARCH RESULT}

\section{Genjer-Genjer Historical Background Songs}

The political changes in Indonesia of the mid-1960s era was marked by the replacement of the president Sukarno by Suharto. When led by Sukarno, Indonesia is decorated with two current strengths both in terms of culture and politics. His form in Political party PKI (Indonesian Communist Party), whereas in a culture characterized by the presence LEKRA (Lembaga Kebudayaan Rakyat) or Cultural Institute where both are in the ideology of socialism. On the other hand, there is also the power of the TNI (Tentara Nasional Indonesia) or Indonesian Armed Forces and Manikebu (Manifes Kebudayaan) or Cultural Manifesto that supports the ideology of Global Capitalism.

The fall of Sukarno put Soeharto as the new leader in Indonesia. Having managed to occupy the number one position of Indonesia, Suharto imposed a genocidal policy by eliminating everything that is synonymous with Sukarno, 
be it advocates, organizations, artists and works. Slaughter carried everywhere with the main reason remove traces of communism in Indonesia. The slogan was "Latent Danger Communists".

One of the elimination of trace is done is the prohibition against Genjer-Genjer song. The song is considered to be synonymous with communists and harmful to Indonesia because when PKI dominate the political map of Indonesia often use the song as a political tool. That's what makes Suharto provide a major concern in this song. Thus, efforts to establish a discourse on the dangers of Genjer-Genjer song featured in the propaganda film of PKI rebellion. In the film, Genjer-Genjer songs played when members of the PKI was fun after torturing and killing several General TNI (Indonesian State Army).

Based on that, a rule issued by the state related to the banning of the communist Suharto in Indonesia. TAP is the Assembly XXV / 1966: Prohibition Understand Communism in Indonesia. This rule applies until now. Thus, all matters relating to communism would always invite the public debate in Indonesia today.

Likewise, the status Gejer-Genjer. And unfortunately, this discourse always been popularly used in every election campaign in Indonesia. Including in the Indonesian presidential election in 2014.

\section{Ojo Kuwi or Genjer-Genjer (Communist Discourse Formation)}

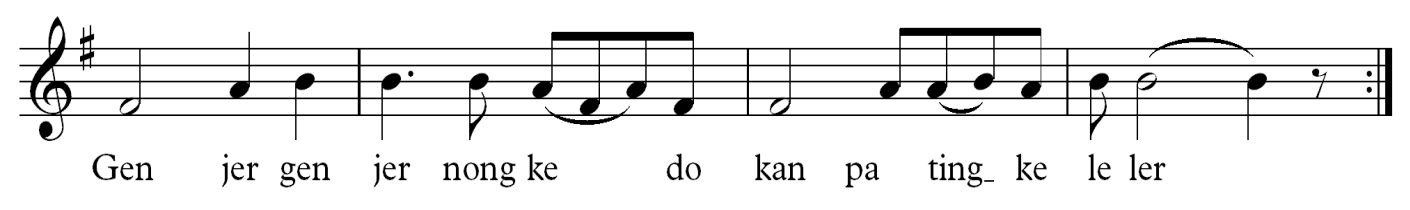

Figure 1. The strains Genjer-Genjer

Pieces sentence above song familiar to the people of Indonesia, especially for people who have felt the new order regime. There is a certain danger when play this song. So that, at the time this song is categorized forbidden. The main cause is the labeling of the communist stamp to this musical work by the government in power at that time.

However, after the song Ojo Kuwi emerged as one of the media campaign, talks about Genjer-Genjer re-heated in Indonesian society. The main question is why the song was banned in Indonesia at a certain time again presented during the Indonesian presidential election campaign in 2014? Many options related to this question. One of them is about the discourse of communism. Ahmad Dhani as a songwriter Ojo Kuwi allegedly plagiarizing a song Genjer-Genjer LEKRA created by artist named Muhammad Arif. 
Many consider that the song Ojo Kuwi has similarities with Genjer-Genjer. It could be considered a song Ojo Kuwi following:

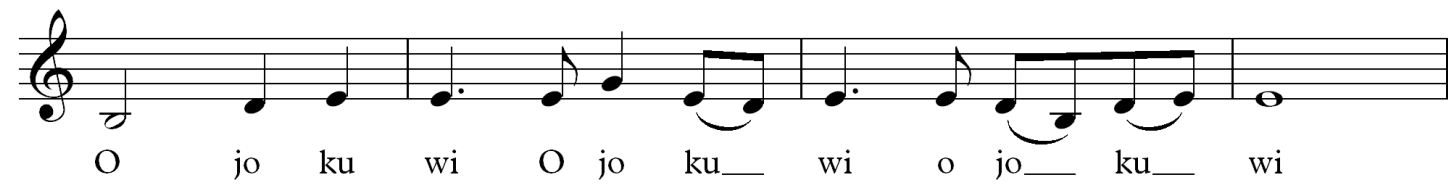

Figure 2. The strains of Ojo Kuwi

In the first bars until the first beat of the second measure looks same melody motive Genjer-Genjer songs contained on the first bars until the first beat of the second measure (see figure 1). In addition, this melody motif also played once in the intro with using an electric guitar.

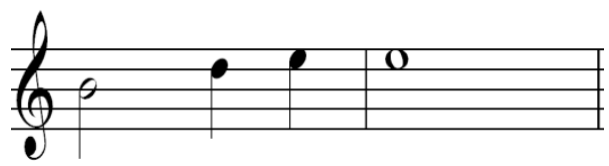

Figure 3. Melody Intro Ojo Kuwi

The melody is the same as the intro song Genjer-Genjer that plays the melody. However, in Genjer-Genjer song melody is played twice. As in the following scores:

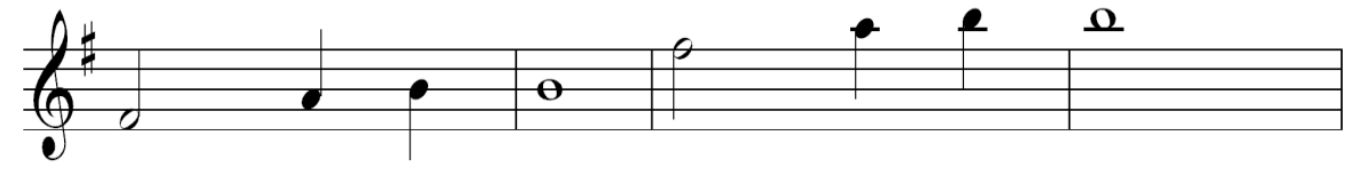

Figure 4. Melody Intro Genjer-Genjer

The existence of this Ojo Kuwi song became the talk in the world of the Internet in Indonesia. One is through the medium of twitter that is exhaled by a director Joko Anwar (Tribunnews.com, 29.06.2014. 22:08). According to the presence of the following Ojo Kuwi song with preaching has accompanied the public discourse into the discourse of PKI. This is evident from some peoples comments contained in commentary columns of the news.

Other talks about the song Ojo Kuwi also discussed by Gerindra party chairman, Suhardi. According to him, linking songs Ojo Kuwi with communism was a hasty decision. While political communication expert from University of Indonesia, Ade Armando assess the actions of Ahmad Dhani as a songwriter Ojo Kuwi is making his own mistakes. According to the similarity of this song with Genjer-Genjer been slapped Gerindra because stigmatization Genjer-Genjer been synonymous 
with communism (Tempo.co, 29.06.2014. 07:20 pm).

From the above, it can be seen since the emergence of the song Ojo Kuwi as media campaigns Prahara team actually bring back the discourse of communism in Indonesia. In fact, Indonesian communism is no longer up to date. However, why this discourse raised again? The event will be missed by providing analysis using the concept below.

Based on the concept of public space is described by Low and Smith (2006), the song Ojo Kuwi non-physical space occupied territories since circulated on Youtube internet media. Apart from that, his conversation also fill the news media and the internet as Tribunnews.com Tempo.com. Ojo Kuwi position in the nonphysical space has become a collective memory of the community in accordance stimulus described by Olick (1999). Whereas the same melody with Genjer-Genjer on each prefix songs and Intro Ojo Kuwi be new information for STM which stimulate the return of memory of past societies that are stored in LTM (Sneyder: 2001).

Found answers that melody Ojo Kuwi revive the collective memory of Indonesian society about the dangers of communist discourse. More emphasized when the discourse is much talked about in the public space in the news Indonesian internet.

\section{Ojo Kuwi as Political Communication Messages}

Kuwi Ojo, Ojo Kuwi, Ojo Kuwi

Kuwi ngono ora biso rumongso

Kuwi ngono rumungso biso

\section{(Ojo Kuwi. Coblos nomer 1!)}

This means:

Do it, do it, do it

That it does not know himself

That it just felt could

\section{(Do it. Vote for number 1!)}

On top of that are the lyrics Ojo Kuwi. This section will discuss the position of this song as a medium of political communication messages. Based on the concept of message box Burton and Shea (2010), there are four key questions in political communication strategies used in the campaign. What do you say about yourself, what they say about you, what you say about them, and what they say about them.

First, What do you say about yourself? When listening to a song Ojo Kuwi, can be found a lyric that says "Ojo Kuwi, Coblos be number 1". This sentence convey a message to the listener to choose the pair number 1 . Message communication is both a call to not choose a partner other than the serial number 1 . It corresponds fourth view of the concept of message box that is what you say about them.

Associated with the lyrics of the song Ojo Kuwi, here message delivered is explained about the candidate presidential opponent's weaknesses serial number 
1. Weakness candidate is described with poetry kuwi ngono ora biso rumongso (which it does not know themselves) and kuwi ngono rumongso iso (which it just felt I could). Indirectly, the song Ojo Kuwi regard opposed presidential couple number 1 has properties not know yourself and just feel you can. Whereas at the beginning of the song lyrics that read Ojo Kuwi repeated three times asserts that people do not choose the presidential candidate. This is consistent with the concept of a fourth message box, which is about what you say about them.

From some of these aspects, it was found that the lyrics of the song Ojo Kuwi made as the interests of political communication. The main thing that communicated the messages that urge people to not choose an opponent from presidential candidate pair number 1.

\section{CONCLUSION}

Emerging song Ojo Kuwi on youtube internet media fill non-physical public space. This public space revive the collective memory of the community about the discourse of communism which once banned during the New Order Indonesia. This is reinforced by the similarity between Ojo Kuwi melody with Genjer-Genjer. Thus, the sameness regenerates hot debate about communism in Indonesia.

Ojo Kuwi song communicate campaign messages presidential candidate number 1 so as not to choose a partner other candidates. Communication message works by inviting the public to choose the number 1 is reinforced by a message at the end of the song. In addition, this song shows the weakness of the opponent candidate number 1 and confirms the initial sentence Ojo Kuwi which means "do it" or do not choose a candidate other than the number 1 .

\section{REFERENCES}

Burton, Michael J \& Shea, Daniel M. 2010. Campaign Craft: The Strategies, Tactics, and Art of Political Campaign Management. California: Praeger.

Guba, Egon G \& Yvonna S. Lincoln. 1994. Competing Paradigms in Qualitative Research. In Norman K. Denzim \& Yvonna S. Lincoln (ed.), Handbook of Qualitative Research. Thousand Oaks: Sage Publications.

Low, Setha \& Niel, Smith. 2006. The Politics of Public Space. NY: Routledge.

Newman, W. Lawrence. 1997. Social Research Methods: Qualitative and Quantitative Approaches. Boston: Allyn \& Bacon

Olick, Jeffrey. 1999. Collective Memory: The Two Culture, Sosiological Theory.

Popkewitz, Thomas S. 1990. Whose Future? Whose Past?: Notes on Critical Theory and Methodology. In Egon G. Guba (ed.), The Paradigm Dialog, Newbury Park: Sage Publications.

Sneyder, Bob. 2001. Music and Memory: An Introduction. Ebook.

\section{Internet}

Tempo.com

Tribunnews.com 